Volume 8

Number 2 Student Articles Edition

Article 6

2-16-2022

\title{
Patently Absurd: The Invention Secrecy Order System
}

Gregory Saltz

Texas A\&M University School of Law (Student), saltz1@tamu.edu

Follow this and additional works at: https://scholarship.law.tamu.edu/journal-of-property-law

Part of the Intellectual Property Law Commons, Military, War, and Peace Commons, and the Property Law and Real Estate Commons

\section{Recommended Citation}

Gregory Saltz, Patently Absurd: The Invention Secrecy Order System, 8 Tex. A\&M J. Prop. L. 211 (2022). Available at: https://doi.org/10.37419/JPL.V8.I2.6

This Notes \& Comments is brought to you for free and open access by Texas A\&M Law Scholarship. It has been accepted for inclusion in Texas A\&M Journal of Property Law by an authorized editor of Texas A\&M Law Scholarship. For more information, please contact aretteen@law.tamu.edu. 


\title{
Patently Absurd: The InVention Secrecy Order System
}

\author{
Gregory Saltz ${ }^{\dagger}$ \\ Abstract
}

The current patent application secrecy order system has almost no safeguards to prevent abuse and overreach into private intellectual property rights by the Government. Defense agencies are presently able to have the United States Patent and Trademark Office place secrecy orders on applications by merely deciding for themselves that revelation of information found therein would be detrimental to national security; there are no rules or restrictions on how the agencies go about making this determination. Likewise, the current system contains little in the way of protection for inventors who are left without a meaningful way to challenge these orders. The prospect of devoting substantial time, money, and resources towards inventing a new technology only for the Government to both prevent inventors from obtaining a patent on it and forbidding them from leveraging such a patent cuts against the incentivization that lies at the heart of a healthy intellectual property regime. An overhaul to this system guaranteeing stronger safeguards and better protections is required to maintain the pace of technological advancement facilitated by the strong private rights afforded by the United States' patent system. This Comment proposes a number of changes to the current statutory and regulatory framework that will create these necessary protections to check Government abuse and to safeguard inventors' rights.

I. INTRODUCTION................................................................... 212

II. THE HISTORY OF INVENTION SECRECY ORDERS ........................ 215

III. SECRECY ORDERS AND THE PROCEDURES BY WHICH THEY ARE

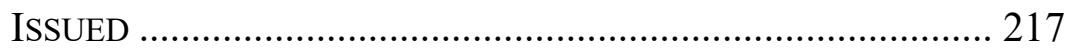

DOI: https://doi.org/10.37419/JPL.V8.I2.6

†Juris Doctor Candidate, Texas A\&M University School of Law-Spring 2022. Bachelor of Science in Nuclear, Plasma, and Radiological Engineering, University of Illinois at Urbana-Champaign-Spring, 2014. Systems Engineer, United States Department of Defense-2015 to 2017. Registered United States Patent Agent2020 to present. 
A. Secrecy Order Procedures ............................................ 217

1. When the Government Has a Property Interest ......... 218

2. When the Government Does Not Have a Property

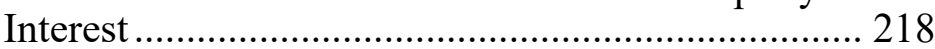

B. Secrecy Order Types................................................... 221

IV. CONSEQUENCES OF SECRECY ORDERS ..................................... 223

A. Consequences for the Application and Applicant ........... 223

B. Options Available to the Applicant ................................... 225

1. Challenging the Secrecy Order .................................. 225

2. Claims for Compensation ......................................... 226

V. NATIONAL SECURITY Policy AND ITS RELATION TO THE ISSUANCE

OF SECRECY ORDERS ………………………………….... 227

A. National Security Policy............................................... 228

B. Weaknesses of the Current Patent Secrecy System .......... 228

C. The Potential for Governmental Abuse and Inventor

Uncertainty ............................................................ 230

VI. Proposed MECHANISMS AND PROCEDURES to RECTIFY the

IDENTIFIED ISSUES ………………………………………..... 231

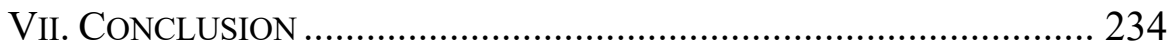

\section{INTRODUCTION}

The Federal Government has reserved for itself the right to place secrecy orders on inventors' patent applications whose disclosure are deemed "detrimental to the national security."1 These orders prevent the United States Patent and Trademark Office ("USPTO") from both publishing or granting a patent on the applications. ${ }^{2}$ Significantly, while such orders nominally last only for one year, the Government may renew them indefinitely. ${ }^{3}$ Thus, an application could legally be kept secret in perpetuity.

Discretion on what is "detrimental" lies almost entirely with the interested governmental agencies - usually members of the Department of Defense or the Intelligence Community. ${ }^{4}$ Specifically, the agencies have compiled a comprehensive list of technical subject-

1. 35 U.S.C. $\S 181$.

2. $I d$.

3. $I d$.

4. Id. Upon notification by the interested agency, the Commissioner of Patents "shall order that the invention be kept secret and shall withhold the publication of the application or the grant of a patent ...." (emphasis added). See also Steven Aftergood, Invention Secrecy Activity, FED'N OF AM. SCIENTISTS, https://fas.org/sgp /othergov/invention/stats.html [https://perma.cc/HWR4-HKB8]. 
matter areas ("SMAs") that, should an application fall within, will trigger a review to see if a secrecy order will be requested (de facto demanded) of the Commissioner of Patents. ${ }^{5}$ While the list is nominally set, whether or not the application in question will be detrimental to national security is at the whim of the agency reviewer. ${ }^{6}$ National security policy as laid out by the executive branch dictates the exact contours of how agencies will review an application. ${ }^{7}$

Given the inherently obfuscated nature of this process and the amount of control that lies within the hands of the agencies, the potential for governmental overreach in the way of secrecy orders on applications - to the detriment of individual inventors specifically and technological innovation generally - is immense. This is particularly so in the current COVID environment, in which agencies could easily deem numerous SMAs, such as biotechnology, to be of great importance to national security.

The recent trend in the Government's issuance of secrecy orders is that it has been continually increasing. In 2010, there were a total of 5,135 inventions under secrecy orders. ${ }^{8}$ This was the highest number in more than a decade. ${ }^{9}$ In 2015 , there were 5,579 applications under secrecy orders. ${ }^{10}$ Following a year-after-year increase, at the end of 2020, there were 5,915 applications. ${ }^{11}$ This is the highest it has been in at least 27 years. ${ }^{12}$ Disconcertingly, some of these were so-called "John Doe" orders - orders placed on private inventors. ${ }^{13}$

The underlying purpose of a patent is to incentivize the development of, and public disclosure of, technological innovations by

5. Armed Servis. Pat. Advisory Bd., Patent Security Category Review LIST 1-2 (1971), https://fas.org/sgp/othergov/invention/pscrl.pdf [https://perma.cc /W4TP-Y2HU] [hereinafter ASPAB].

6. See infra Section III.A.

7. See infra Part V.

8. Steven Aftergood, Invention Secrecy Still Going Strong, FED'N OF AM. SCIENTISTS (Oct. 21, 2010), https://fas.org/blogs/secrecy/2010/10/invention_secrecy_2010/[https://perma.cc/S3LH-JKRX].

9. Id.

10. Steven Aftergood, Invention Secrecy Activity, FED'N OF AM. SCIENTISTS, https://fas.org/sgp/othergov/invention/stats.html [https://perma.cc/HWR4-HKB8].

11. Id.

12. Steven Aftergood, Invention Secrecy Hits Recent High, FED'N OF AM. SCIENTISTS (Oct. 31, 2018), https://fas.org/blogs/secrecy/2018/10/invention-secrecy -2018/ [https://perma.cc/K62Y-P8VJ]. "The new total of 5,792 secrecy orders in effect is the highest since 1993, when the total was 5,909."

13. Steven Aftergood, Invention Secrecy Activity, FED'N OF AM. ScIENTISTS, https://fas.org/sgp/othergov/invention/stats.html [https://perma.cc/HWR4-HKB8]. 
granting time-limited monopolies to inventors. After the expiration of the monopoly, anyone is free to practice the art in question. Because of the powerful exclusionary rights of this monopoly, ${ }^{14}$ the burdens to receiving a patent are quite high, especially compared to other forms of intellectual property, such as copyrights. While there has always been a balancing act between monopoly and incentivization, the prospect of a secrecy order may act as the "bridge too far" for many inventors. ${ }^{15}$ Many will be wary of the arduous and expensive process of prosecuting a patent application only for the Government to turn around and prevent them from using or even disclosing the fruits of their inventive labor. This is particularly so with the aforementioned "John Doe" inventors who cannot so easily eat the financial costs like a large corporation could. Concordantly, these inventors, dissuaded from seeking patent protection, may rely on trade secret status instead, which has no time limitation and (obviously) does not inform the public on how to make and use a potentially beneficial advancement in the art.

This Comment does not take the position that secrecy orders ought to be done away with entirely. A public disclosure is by extension, irrevocably, a disclosure to enemies and adversaries of the United States. Their awareness of sensitive technologies can impede the Government's ability to protect the citizenry by, inter alia, undermining our defense organs' technological superiority. Thus, there are undoubtedly valid instances in which the Government will need to keep a new technology seen in a patent application secret. The problem is not classification ${ }^{16}$ per se, but the immense potential for overreach by governmental agencies due to the sparse limitations on what they can have classified, minimal opportunity to challenge a secrecy

14. 35 U.S.C. $\S 154(a)(1)$. These rights include the right to "exclude others from making, using, offering for sale, or selling the invention throughout the United States or importing the invention into the United States."

15. This is an American expression referencing the failed OPERATION: MARKET-GARDEN from WWII. It refers to an obstacle or challenge that, while not necessarily easy or trivial, would none-the-less be overcome but for the fact that so much adversity has already been encountered, which has worn one down too much.

16. Exec. Order No. 13,526, 75 Fed. Reg. 707-08 (Jan. 5, 2010). This refers to the process of designating something as secret with there being different levels of secrecy based on the expected amount of harm to national security that would result if the relevant information were to leak: confidential-damage; secret-serious damage; top secret - exceptionally grave damage; et cetera. 
order by inventors, and the agencies' wide discretion on the matter that comes with little oversight. Accordingly, this Comment instead proposes statutory and administrative procedures to act as a check on the above in order to simultaneously prevent abuse and maintain the incentive structure that lies at the heart of the patent system.

First, this Comment will briefly go over the history behind invention secrecy legislation. Next, it will detail the procedure by which a patent application is made secret. It will then discuss the consequences of such secrecy orders, both for the application as well as the applicant. Following this, it will highlight the impact of national security policy on the issuance of secrecy orders with an emphasis on the potential for governmental overreach on private intellectual property rights. Finally, this Comment proposes mechanisms to prevent this overreach.

\section{THE History OF INVENTION SECRECY ORDERS}

The origins of the modern invention secrecy system come from the United States' involvement in the First World War. ${ }^{17}$ Following its official entry into the war, Congress was concerned about the fact that "those inventions which are of most use to the Government during a time of war are also those which would, if known, convey useful information to the enemy." 18 Accordingly, Congress sought to prevent the public disclosure of certain patents and passed the Act of October 6, 1917. ${ }^{19}$ Chapter 95 of the Act authorized the USPTO's Commissioner of Patents to order certain inventions be kept secret, preventing their disclosure, "during a time when the United States is at war" if, in his opinion, the invention "might . . . be detrimental to the public safety or defense or might assist the enemy or endanger the successful

prosecution of the war." ${ }^{20}$ Beyond this, the chapter succinctly laid out the consequences for violating the order - the application would be held abandoned - and a means for applicants to seek compensation for their applications having been made secret-bringing suit in the Court of Claims. ${ }^{21}$ Since Congress intended the Act to be temporary, it felt little need to establish an elaborate invention secrecy framework. As

17. S. REP. No. 65-119, at 1 (1917).

18. Id.

19. H.R. 4960, 65th Cong. (1917) (enacted).

20. $I d$.

21. Id. 
stated above, the Commissioner's powers applied only during wartime, and so, with World War I's close on November 11, 1918, use of invention secrecy orders ceased and those applications affected were allowed to issue as patents. ${ }^{22}$

For more than 20 years during the inter-war period, this return to normalcy prevailed. ${ }^{23}$ However, after the Second World War broke out, Congress once again began to have concerns, especially as it seemed more and more likely that the United States would, once again, have to become involved in the hostilities. In preparation for any such entry into the conflict, Congress passed the Act of July 1, 1940. ${ }^{24}$ As a part of it, Chapter 501 effectively reinstated all of the provisions of the 1917 Act. $^{25}$ The only major change was that the effective period would last for only two years. ${ }^{26}$ This, however, was also subsequently changed back to the 1917's duration-of-the-war provision once the United Stated did indeed enter the war. ${ }^{27}$

The Act of August 21, 1941, however, also added numerous provisions which went beyond those of the 1917 Act: stiffer penalties for applicants that willfully violated a secrecy order-in addition to their application being held abandoned, they could face up to a $\$ 10,000$ fine and up to two years incarceration; exceptions for Government workers acting under proper authority; and the chapter was, on a general level, made more specific and fleshed out. ${ }^{28}$ Altogether, this incarnation of the invention secrecy order system much more closely resembled the modern one, with some provisions carried forward verbatim. ${ }^{29}$ Regardless, just as with the 1917 Act, the cessation of hostilities brought an end to the World War II invention secrecy system. ${ }^{30}$ This end, however, was once again only temporary.

With the rise of Cold War tensions between the newly established superpowers of the United States and the Soviet Union, concerns about patent secrecy again came to the forefront. Espionage operations

22. Id. The relevant portion of the Act reads "and withhold the grant of a patent until the end of the war."

23. Id.; H.R. 10058, 76th Cong. (1940) (enacted).

24. H.R. 10058.

25. Compare id., with H.R. 4960.

26. H.R. 10058.

27. S. 2427, 77 th Cong. (1942) (enacted).

28. H.R. 4784, 77th Cong. (1941) (enacted).

29. Compare id., with H.R. 4687, 82nd Cong. (1952) (enacted).

30. S. 2427. 
conducted by the Soviet Union had enabled them to rapidly catch up technologically to the United States. ${ }^{31}$ Perhaps most alarming was the confession in 1950 by Klaus Fuchs, a member of the Manhattan Project, that he passed vital nuclear weapons information on to the Soviets. ${ }^{32}$ By this point, the Department of Defense ("DoD") repeatedly urged Congress to reestablish patent secrecy protocols. ${ }^{33}$ Acknowledging the need for such a peace-time system, Congress eventually passed the Invention Secrecy Act of 1951, which is the legal source for the secrecy orders issued today. ${ }^{34}$ The Act has been amended and expanded upon throughout the years, giving rise to an elaborate system with numerous complexities, caveats, and consequences.

\section{SECRECY ORDERS AND THE PROCEDURES BY WHICH THEY ARE ISSUED}

This section of the Comment will discuss the different types of secrecy orders and the procedures by which the Government can place them on patent applications, as well as the associated sources of law that empowers it to do so.

\section{A. Secrecy Order Procedures}

As a preliminary matter, the exact procedure utilized depends on whether the Government has a property interest in the invention at issue. ${ }^{35}$ This is because inventions the Government either owns outright or had a hand in developing are property that it may volitionally do with as it pleases. ${ }^{36}$ Id est: it can freely choose to make its own patent applications secret or not, whereas with private inventions there are (at least theoretically) higher hurdles.

31. John E. Haynes \& Harvey Klehr, Venona: Decoding Soviet ESPIONAGE IN AMERICA 333 (2000) (ebook).

32. Klaus Fuchs Confesses, THE NAT'L ARCHIVES, https://www.nationalarchives.gov.uk/education/resources/cold-war-on-file/klaus-fuchs-confesses [https://perma.cc/M8VG-WHV8].

33. H.R. REP. NO. 96-1540, at 1 (1980).

34. See generally H.R. 4687 (codified as amended at 35 U.S.C. $\S ~ 181-188$ ).

35. 35 U.S.C. $\S 181$.

36. See 37 C.F.R. $\S 501.6(2020)$. 


\section{When the Government Has a Property Interest}

The Government is said to have a property interest in inventions made by Government employees:

(1) during working hours, or (2) with a contribution by the Government of facilities, equipment, materials, funds, or information, or of time or services of other Government employees on official duty, or (3) which bear a direct relation to or are made in consequence of the official duties of the inventor. ${ }^{37}$

The Government must register such applications where it has a property interest in the USPTO's Government Register. ${ }^{38}$ Unlike applications where the Government does not have a property interest, these applications are not screened by the Patent Office ${ }^{39}$ and will not be forwarded on to any defense agencies. ${ }^{40}$ It is the responsibility of the agency to which the Government employee in question belongs, or which is otherwise involved, to request a secrecy order. ${ }^{41}$

A secrecy order is brought about by the heads of the agencies merely giving notice to the Commissioner of Patents. ${ }^{42}$ The only qualification to this is that the agency head must determine that disclosure of the application "might . . . be detrimental to the national security." 43 This power also extends to anyone to whom the agency head has delegated such authority. ${ }^{44}$ As a general matter, however, undertakings by Government employees (by definition) do not implicate the potential for overreach into private intellectual property rights. ${ }^{45}$ Accordingly, this Comment is not concerned with this procedure.

\section{When the Government Does Not Have a Property Interest}

When the Government does not have a property interest in the invention, the procedure is somewhat different and there is a slightly higher burden on the Government. ${ }^{46}$ All patent applications are first

37. $I d$.

38. 37 C.F.R. $\$ 3.58$ (2020).

39. MPEP $\S 115$ (9th ed. 2020) [hereinafter MPEP].

40. 37 C.F.R. $§ 5.1(\mathrm{f})$.

41. MPEP, supra note 39, § 115.

42. 35 U.S.C. $\$ 181$.

43. $I d$.

44. $\S 188$.

45. See $\S 181$.

46. See id. 
sent to the Licensing and Review Branch of the USPTO's Special Laws Administration Group, commonly referred to as Group 220.47 Group 220 examiners conduct a so-called "secrecy review" on each application to see if it contains information the disclosure of which might be detrimental to national security. ${ }^{48}$ Guiding their inquiry are several lists that contain different categories of inventions and technologies, which are grouped into subject-matter areas. ${ }^{49}$

The most important of these lists is the Patent Security Category Review List ("PSCRL"), which is compiled by the DoD through the Armed Services Patent Advisory Board ("ASPAB"). ${ }^{50}$ The PSCRL is supplemented by several additional lists: ${ }^{51}$ (1) the Militarily Critical Technologies List ("MCTL"), published by the Defense Technical Information Center of the $\operatorname{DoD}^{52}(2)$ the Commerce Control List ("CCL"), which is a part of the Export Administration Regulations ("EAR") enforced by the Bureau of Industry and Security within the Department of Commerce; ${ }^{53}$ and (3) the United States Munitions List ("USML"), which is a part of the International Traffic in Arms Regulations ("ITAR") enforced by the Directorate of Defense Trade Controls within the Department of State. ${ }^{54}$

Both the PSCRL and MCTL list technologies that ostensibly have the potential to harm national security if associated technical information were made public. ${ }^{55}$ The CCL and USML, on the other hand, deal with technologies subjected to export restrictions requiring

47. MPEP, supra note 39, § 115; H.R. REP. No. 96-1540, at 17 (1980).

48. MPEP, supra note $39, \S 115$.

49. ASPAB, supra note 5, at 1-2.

50. Id.

51. The Secrecy Order Program in the United States Patent \& Trademark Office, FED'N OF AM. SCIENTISTS, https://fas.org/sgp/othergov/invention/program.html [https://perma.cc/X552-5HTN] (last revised June 27, 1991) [hereinafter Secrecy Order Program].

52. See Militarily Critical Technologies List, NAT'L OCEANIC \& ATMOSPHERIC ADMIN., https://www.wrc.noaa.gov/wrso/security_guide/mctl.htm [https://perma.cc /KUK8-V438] (last updated Nov. 28, 2001).

53. Commerce Control List, BuREAU OF INDUS. AND SEC., https:/ /www.bis.doc.gov/index.php/regulations/commerce-control-list-ccl [https:/ /perma.cc/FA2D-28VL].

54. The International Traffic in Arms Regulations (ITAR), DIRECTORATE OF DEF. TRADE CONTROLS, https://www.pmddtc.state.gov/ddtc_public?id=ddtc_kb article_page\&sys_id=24d528fddbfc930044f9ff621f961987- [https://perma.cc /MWY9-DT9Y].

55. See ASPAB, supra note 5, at 1-2; Militarily Critical Technologies List, supra note 52 . 
governmental authorization. ${ }^{56}$ Should a patent application describe any of the technologies on these lists, then Group 220 forwards it on to the appropriate agencies designated as being involved in national defense by the President and solicits their opinion on whether disclosure of the invention would harm national security. ${ }^{57}$ Critically, none of the above lists hold themselves out as being exhaustive; the ASPAB, for example, has stated on the PSCRL that it wishes to "examine any application which ... has significant use in aeronautical and space activities." 58

At this stage, the agencies review the application; just like when the Government does have a property interest, agency heads can delegate decision-making authority on this matter. ${ }^{59}$ The only criterion that they must comply with is the statutory burden that the application's disclosure "would be detrimental to the national security," vice "might . . . be detrimental," as is the case when the Government has a property interest. ${ }^{60}$ There are no other requisites, meaning that agencies are completely free to make this determination in any manner they choose. ${ }^{61}$ If they determine that national security would be harmed, then they notify the Commissioner of Patents, who must then order the application be made secret. ${ }^{62}$ For agencies within the DoD, the ASPAB coordinates this exchange, ${ }^{63}$ whereas non-DoD agencies notify the Commissioner directly. ${ }^{64}$ Of the thousands of applications that fall within a PSCRL SMA and that are subsequently reviewed by defense agencies, five to ten percent are subjected to secrecy orders. ${ }^{65}$ Upon the issuance of a secrecy order, the applicant is subsequently notified. ${ }^{66}$

56. See Secrecy Order Program, supra note 51.

57. 35 U.S.C. $§ 181$.

58. ASPAB, supra note 5, at 2 (emphasis added).

59. 35 U.S.C. $\S 188$.

60. $\S 181$ (emphasis added).

61. See $\S 188$.

62. $\$ 181$.

63. Secrecy Order Program, supra note 51.

64. MPEP, supra note $39, \S 115$.

65. Sabing H. Lee, Protecting the Private Inventor under the Peacetime Provisions of the Invention Secrecy Act, 12 BERKELEY TECH. L.J. 345, 363 (1997).

66. 35 U.S.C. $\S 181$. 


\section{B. Secrecy Order Types}

There are three types of secrecy orders. ${ }^{67}$ Type I secrecy orders - "Secrecy Order and Permit for Foreign Filing in Certain Countries"- are issued in accordance with DoD Directive 5230.25, which derives its authority from 10 U.S.C. $\S 130$ and acts as a form of export control. ${ }^{68}$ The Directive allows the DoD to prevent disclosure of technical data pertaining to military or space applications that the DoD currently possesses if such data is subject to either the ITAR or EAR and cannot be lawfully exported without governmental approval, authorization, or license. ${ }^{69}$ Unlike the other orders, Type I orders concern applications only containing otherwise unclassified information. ${ }^{70}$ Also, Type I orders are only issued at the request of the Department of Defense. ${ }^{71}$

Although Directive 5230.25 explains the general policies and procedures DoD agencies use to determine if something should be withheld from public disclosure, there is little substantive information on what guides its decision-making process for the underlying determination; ${ }^{72}$ the Directive simply refers back to the MCTL, which serves as "general guidance." 73 The Directive is primarily concerned with explaining the types of situations in which certain disclosures could be permitted $;{ }^{74}$ id est, permission is unsurprisingly not guaranteed. $^{75}$

Type II orders - "Secrecy Order and Permit for Disclosing Classified Information"-concern patent applications that contain classified or otherwise classifiable information and which are submitted by applicants who already have a DoD security agreement. ${ }^{76}$ These orders are simply an extension into patent examination of the general requirements of secrecy: the relevant technical data in the application

67. MPEP, supra note $39, \S 120$.

68. Id.; Withholding of Unclassified Technical Data from Public Disclosure, 32

C.F.R. § 250 (1984). See also 10 U.S.C. § 130.

69. 32 C.F.R. $\$ 250$.

70. MPEP, supra note 39, § 120; Secrecy Order Program, supra note 51.

71. Secrecy Order Program, supra note 51.

72. See generally 32 C.F.R. $\$ 250$.

73. $\S 250.5(\mathrm{~b})(2)$.

74. See generally $\S 250$.

75. See § 250.4(c) ("Notwithstanding the authority (to withhold certain information from public disclosure) provided in paragraph 4.1., above, it is DoD policy to ....") (emphasis added).

76. MPEP, supra note $39, \S 120$. 
will receive a security classification and may only be disclosed to persons holding an appropriate security clearance. ${ }^{77}$ Executive Order 10865, Executive Order 12356, or the security agreement-DD Form 441 - dictate information classification. ${ }^{78}$ Because Type II orders concern applicants who have already signed a DoD security agreement, they are of little importance to this Comment.

Type III orders - “General Secrecy Order"- - are the most critical to this discussion. This category acts as a catch-all, enabling Government agencies to put secrecy orders on anything that does not fall within the first two categories. ${ }^{79}$ This enablement has the greatest potential for governmental overreach due to its breadth and the ability for any agency to make use of it.

Because of the intricacies involved with this somewhat elaborate landscape, the ASPAB has issued guidelines on what type of secrecy order it will recommend the agency request on a given application in line with what each of the orders is principally directed towards. ${ }^{80}$ If the technical information is unclassified, the ASPAB determines if the guidelines in the classified section of the MCTL control its export. ${ }^{81}$ If it is, a Type I order is recommended ${ }^{82}$ Based on which section of the MCTL is implicated, the ASPAB uses the associated unclassified cross-reference to obtain the proper respective Export Control Classification Number ("ECCN") from either the CCL or the ITAR, which is included in the recommendation. ${ }^{83}$

If the information is classified or classifiable, a Type II secrecy order is recommended, provided the applicant has a current DoD security agreement. ${ }^{84}$ To determine whether there is a security agreement, the ASPAB can reach out to the relevant DoD security offices, which maintain this information. ${ }^{85}$ A Type III secrecy order is recommended if the applicant does not have a current security agreement. ${ }^{86}$

77. Id. See also Secrecy Order Program, supra note 51.

78. Exec. Order No. 10,865, 3 C.F.R. 398 (1959-1963); Exec. Order No. 12,356, 3 C.F.R. 166 (1982); MPEP, supra note 39, § 120.

79. See MPEP, supra note $39, \S 120$.

80. Secrecy Order Program, supra note 51.

81. Id.

82. $I d$.

83. Id.

84. Id.

85. Id.

86. $I d$. 


\section{CONSEQUENCES OF SECRECY ORDERS}

This section of the Comment will discuss what the consequences of a secrecy order are for both the patent application and the applicant, as well as what, under current regulations and procedures, an applicant can do to challenge the order.

\section{A. Consequences for the Application and Applicant}

A secrecy order lasts for a period of one year or, during wartime, until one year after the cessation of hostilities. ${ }^{87}$ During this time, as the name of the order states, no information pertaining to the invention can be disclosed to anyone not already aware of it and the USPTO will not allow it to issue as a patent. ${ }^{88}$ Critically, upon mere notification by the agency, "[t]he Commissioner of Patents shall renew the order." 89 Thus, an agency could keep an application secret indefinitely; ${ }^{90}$ there have been several cases where a secrecy order remained in place for more than 25 years. ${ }^{91}$ Obviously, because the public cannot review applications made secret, it is fully possible that there are currently cases of secret applications whose durations have gone on far longer and simply have not yet had the secrecy order lifted yet.

Although an application with a secrecy order cannot issue as a patent, an examiner with an appropriate security clearance will still examine it. ${ }^{92}$ The application will not, however, be made the subject of an interference or derivation proceeding. ${ }^{93}$ Further, rejected applicants cannot appeal to the (now referred to as) Patent Trial and Appeal Board ("PTAB") unless the Commissioner specifically orders such action. ${ }^{94}$ Despite this, the applicant must still timely respond to office actions or else the application is considered abandoned, as per normal. ${ }^{95}$

87. 35 U.S.C. $\S 181$.

88. Id. See also § 186.

89. § 181 (emphasis added).

90. $\S \S 181-188$. There is nothing within the Invention Secrecy Act of 1951 that states a maximum duration of time that an application may be kept secret for.

91. Stein v. United States, 135 F. Supp 2d 265, 276 (D. Mass. 2001) (where the invention was made secret for twenty-seven years); Am. Tel. \& Tel., Co. v. United States, 685 F.2d 1361, 1361-62 (Ct. Cl. 1982) (where the invention was made secret for twenty-eight years).

92. MPEP, supra note $39, \S 130$.

93. 37 C.F.R § 5.3(b) (2020). See also id.

94. MPEP, supra note $39, \S 130$.

95. 37 C.F.R. § 5.3(a). See also id. 
An agency lifts a secrecy order by either not renewing it or by notifying the Commissioner that disclosure of the application will no longer be detrimental to national security. ${ }^{96}$ Once this occurs, appeals before the PTAB may proceed. Following any such appeals, and provided that all other requisites of examination are met, the Patent Office will issue a notice of allowance. ${ }^{97}$

Under the current U.S. patent system, an issued patent has a lifetime of 20 years from its filing date..$^{98}$ To address obvious problems of fairness, Congress permitted extensions of patent terms in certain situations, including that of secrecy orders. If an application is subjected to such an order, mercifully, its term is extended by one day for each day of the pendency of the order. ${ }^{99}$

There are also, however, severe consequences for the application for any unauthorized disclosures. If an application under secrecy is disclosed or published without the authorization of the Commissioner, it is held abandoned. ${ }^{100}$ The same is true for unauthorized filings in foreign patent offices. ${ }^{101}$ Such foreign filings, as with non-secret applications, ${ }^{102}$ require a foreign filing license. ${ }^{103}$ In both cases, the Commissioner cannot give authorization without consent from the agency that brought about the secrecy order in the first place. ${ }^{104} \mathrm{Con}-$ sent may, for example, be given for a disclosure made to a person with an appropriate security clearance or for a foreign filing made with a loyal ally of the United States. ${ }^{105}$

Just like with the application, there are also severe consequences for the applicant should he or she make an unauthorized disclosure. Should an inventor willfully violate a secrecy order by publication, disclosure, or filing in a foreign office, the penalty can be as harsh as a $\$ 10,000$ fine, as well as a two-year incarceration. ${ }^{106}$ Further, violations pertaining to certain specific SMAs, should the application carry a security classification, could result in an additional criminal

\footnotetext{
96. 35 U.S.C $\S 181$.

97. 37 C.F.R. $\$ 5.3(\mathrm{c})(2020)$.

98. 35 U.S.C. $\S 154(\mathrm{a})(2)$.

99. § 154(b)(1)(C).

100. $\$ 182$.

101. $\S \S 182,185$.

102. MPEP, supra note $39, \S 140$.

103. 35 U.S.C. $\S 184$.

104. $\S \S 182,184$.

105. See 37 C.F.R. \& 5.5(b)-(c) (2020).

106. 35 U.S.C. $\S 186$.
} 
charge carrying a penalty of up to ten years imprisonment. ${ }^{107}$ The applicant also forfeits any and all claims for compensation against the Government (see next section). ${ }^{108}$

\section{B. Options Available to the Applicant}

Overall, there are only limited means by which an applicant can challenge the validity of a secrecy order. The only formal mechanisms available are a petition for rescission made to the Commissioner of Patents, or an appeal to the Secretary of Commerce. ${ }^{109}$ Additionally, an applicant may seek compensation. ${ }^{110}$

\section{Challenging the Secrecy Order}

An applicant may challenge a secrecy order as being either issued erroneously or as overly broad. ${ }^{111}$ The Manual of Patent Examining Procedure ("MPEP") recommends an informal process of directly contacting the agency that requested the order to discuss possible ways of rescission, such as by expunging subject matter from the application that the agency deemed sensitive. ${ }^{112}$ If successful, then the application - appropriately redacted if necessary - can continue on its path to issuance once the Commissioner receives notice from the agency that disclosure of the application will no longer be detrimental to national security. ${ }^{113}$

If the applicant desires to undertake a formal process, the first option is to petition the Commissioner for rescission. ${ }^{114}$ Such a petition must "recite any and all facts that purport to render the secrecy order ineffectual or futile." 115 As to the second option, an applicant cannot make an appeal to the Secretary of Commerce until "after a petition for rescission of the secrecy order has been made and denied." 116 Further, the applicant must appeal "within sixty days from

107. See, e.g., 18 U.S.C. $\$ 798$.

108. 35 U.S.C. $\$ 182$.

109. 37 C.F.R. $\$ 5.4(2020)$.

110. 35 U.S.C. $\S 183$.

111. Lee, supra note 65 , at 366 .

112. MPEP, supra note $39, \S 120$.

113. 37 C.F.R. $\$ 5.1(\mathrm{e})(2021)$.

114. 37 C.F.R. $\S \S 5.1(a), 5.4(a)(2021)$.

115. $§ 5.4(b)$.

116. $§ 5.4(d)$. 
the date of the denial." 117 Either the Secretary or the person to whom the Secretary has properly delegated authority hears and decides the outcome of the appeal. ${ }^{118}$ Importantly, in all of the above routes, the official in question sets the rules on how to make a determination. ${ }^{119}$

\section{Claims for Compensation}

Aside from the above challenges, an applicant is also permitted to seek "compensation for the damage caused by the order of secrecy and/or for the use of the invention by the Government." 120 There are two ways to seek this compensation: an administrative route and a judicial route. ${ }^{121}$

As an initial matter, the courts have held that the Government has the "absolute power to take a compulsory, nonexclusive license to a patented invention at will" under 28 U.S.C. $\S 1498,{ }^{122}$ which has been construed as an eminent domain statute. ${ }^{123}$ Inventors may redress such use with "reasonable and entire compensation" by suing the Government in the U.S. Court of Federal Claims. ${ }^{124}$

In the administrative route, the claimant's application must first be in condition for allowance. ${ }^{125}$ Once it is, a claim can be brought against the agency, which is authorized to enter into a "full settlement for the damage and/or use." 126 The latter category has an additional criterion in that the right to seek compensation begins on the first date on which the Government actually used the invention. ${ }^{127}$ If the two parties agree to an amount, then this settlement becomes "conclusive for all purposes" and cannot be later renegotiated. ${ }^{128}$ If no settlement is reached, the agency instead determines on its own an amount that constitutes "just compensation" and awards the applicant not more

117. Id.

118. 35 U.S.C. $\S 188$.

119. $\S \S 181,188$.

120. $\S 183$.

121. See id.

122. Brunswick Corp. v. United States, 36 Fed. Cl. 204 (1996), aff'd, 152 F.3d 946 (Fed. Cir. 1998).

123. Irving Air Chute Co. v. United States, 93 F. Supp. 633 (Ct. Cl. 1950).

124. 28 U.S.C. $\$ 1498$.

125. 35 U.S.C. $\$ 183$.

126. $I d$.

127. Id.

128. Id. 
than $75 \%$ of this. ${ }^{129}$ At this point, the applicant can now bring suit in either the United States Court of Appeals for the Federal Circuit ("Federal Circuit") or the district court in which he or she resides to recover an additional amount that, when added to the agency's dictated settlement, "constitute[s] just compensation." 130

In the judicial route, the applicant cannot have undertaken the above administrative route and must first wait until the application issues as a patent. ${ }^{131}$ This, of course, means that the secrecy order must first either expire or be rescinded. ${ }^{132}$ Once the patent has issued, the applicant can bring suit in the Federal Circuit for "just compensation for the damage caused by reason of the order of secrecy and/or use by the Government of the invention resulting from his disclosure."133 This is capped by a statute of limitations of six years after issuance, however. ${ }^{134}$ As with the administrative route, the right to seek compensation for use begins on the first date on which the Government actually used the invention. ${ }^{135}$

\section{NATIONAL SECURITy PoliCy AND ITS RELATION TO THE ISSUANCE OF SECRECY ORDERS}

This section of the Comment will first discuss how a given administration's national security policy comes about and how it impacts the various relevant defense agencies' own policies, along with other ways by which the executive branch can influence agency policy. It will then review the weaknesses within the previously discussed patent secrecy order system. Finally, it will both explain (1) the immense potential for governmental overreach into private intellectual property rights by showing how the Government could easily take advantage of the aforementioned weaknesses through said policies, and (2) how all of the above collectively creates considerable uncertainty for inventors vis-à-vis changes brought by a new administration.

129. Id.

130. Id.

131. Id.

132. See $\S 181$.

133. $§ 183$.

134. Id.

135. Id. 


\section{A. National Security Policy}

National security policy is dictated by the executive branch. The President, as Commander-in-Chief, lays out his or her administration's National Security Strategy as required by the Goldwater-Nichols Department of Defense Reorganization Act. ${ }^{136}$ Although the Strategy is ostensibly nothing more than a simple, general document that apprises Congress of an administration's national defense capabilities and aims, ${ }^{137}$ it also informs the national defense agencies on how they are to shape their own, more specific policies. ${ }^{138}$ In creating these policies, the designated agency executives are to conform to the dictates found within the President's Strategy document. ${ }^{139}$ This includes, for example, the DoD's National Defense Strategy, which is issued by the Secretary of Defense, ${ }^{140}$ and the National Military Strategy, which is issued by the Chairman of the Joint Chiefs of Staff. ${ }^{141}$

The President is not limited to only the National Security Strategy for controlling agency policy. Amongst other options, he or she can also issue executive orders to particular agencies directly. ${ }^{142}$ Like the National Security Strategy, these are binding with regards to how the agencies form their internal policies. ${ }^{143}$

\section{B. Weaknesses of the Current Patent Secrecy System}

As previously discussed, agencies have almost complete control on what applications they can have the USPTO make secret. ${ }^{144}$ Despite a nominal framework for when the USPTO will forward an application on to an agency for review - the PSCRL - this guidance and its supplements are non-exhaustive, and those that promulgate these lists frequently request to see all applications pertaining to various, broad subject-matter areas. ${ }^{145}$ Further, the lists have historically contained a staggering amount of SMAs, many with substantial non-

136. Goldwater-Nichols Department of Defense Reorganization Act of October 4, 1986, Pub. L. No. 99-433, 100 Stat. 992, 1074-75.

137. See generally 50 U.S.C. $\$ 3043$.

138. See, e.g., 10 U.S.C. $\S 153(b)(1)(C)(i)$.

139. See, e.g., id.

140. $\S 113(\mathrm{~g})(1)(\mathrm{A})$.

141. $\S 153(b)$.

142. See, e.g., § 153(b)(1)(C)(v).

143. See, e.g., id.

144. See discussion supra Section III.A.

145. See discussion supra Section III.A. 
defense applications. ${ }^{146}$ Such technologies include lasers, photovoltaic solar energy technology, and gyroscopes, amongst many others. ${ }^{147}$

Particularly troublesome is that the public is not privy to what the current guidance lists consist of. While the 1971 PSCRL is available by way of a Freedom of Information Request, the current list of SMAs is still not public. ${ }^{148}$ A Freedom of Information request for it has also been made but was denied; an appeal is currently pending. ${ }^{149}$ Because of this, the list could already include or easily be modified to include virtually any technology area.

The only statutory limitation on the agencies is that they must determine that disclosure of a given application would be detrimental to national security; how they go about this determination is entirely up to them. ${ }^{150}$ They are free to establish any rules and regulations to govern this decision-making process, but they are under no obligation to do so, leaving them with a free-handed ability to decide upon a given matter in any way they so choose-even capriciously. ${ }^{151}$ The only statutory protection offered to affected applicants is the ability to appeal a secrecy order to the Secretary of Commerce who, like the agencies, decides on the matter according to his or her own rules. ${ }^{152}$ All the other provisions of the Invention Secrecy Act deal with the consequences should an applicant violate a secrecy order, the applicant's right to seek compensation, et cetera; ${ }^{153}$ they do not establish any additional limitations on the Government or any safeguards to protect inventors. $^{154}$

Worse, the Government has already established a willingness to forgo what limited protection exists: 37 C.F.R. section 1.183 states that "[i]n an extraordinary situation, when justice requires, any requirement of the regulations in this part which is not a requirement of the statutes may be suspended or waived by the Director [of Patents]

146. ASPAB, supra note 5.

147. See id.

148. Steven Aftergood, Invention Secrecy Still Going Strong, FED'N OF AM. SCIENTISTS (Oct. 21, 2010), https://fas.org/blogs/secrecy/2010/10/invention_secrecy_2010/[https://perma.cc/S3LH-JKRX].

149. Id.

150. See discussion supra Section III.A.

151. See 35 U.S.C. $§ 188$ ("[Agencies] may separately issue rules and regulations ..." (emphasis added)).

152. $\S 181$.

153. See discussion supra Section III.A.

154. See $\S \S 181-188$. 
or the Director's designee, sua sponte ...."155 If invoked, this would mean that only the statutory provisions would remain in effect, which would enable the Government to take advantage of a glaring loophole. Technically, the statutes only provide that one can appeal a secrecy order to the Secretary of Commerce; ${ }^{156}$ they do not provide that one can petition the Commissioner, as this is found only within the associated regulations. ${ }^{157}$ These same regulations, however, also require that one first petition the Commissioner before making an appeal to the Secretary. ${ }^{158}$ If the Government wanted to be particularly devilish, they could disallow one's ability to petition the Commissioner by suspending 37 C.F.R. sections 5.4(a)-(c) but retain the requirement that one must first do so before being allowed to appeal to the Secretary as per 37 C.F.R. section 5.4(d). In effect, they could lock the appeal door and place the needed key behind it.

\section{The Potential for Governmental Abuse and Inventor Uncertainty}

The combination of (1) the extremely limited statutory and regulatory protections; (2) the near total discretion on the part of agencies on what SMAs they can have secrecy orders issued on; and (3) the amount of control that the executive branch has on agency policy means that the White House can effectively dictate what technologies are made secret and can do so on a whim. The President need merely issue, say, an executive order to all agencies requiring them to "request" application secrecy orders on applications including material XYZ. The agencies would then update their internal policies to reflect the will of the President and would thereafter take appropriate steps to see it done, such as by adding new categories to the PSCRL. Further, the loophole present in the regulations could be easily exploited during the ongoing COVID pandemic, as this would easily qualify as an "extraordinary situation" under 37 C.F.R. section 1.183 .

Additionally, the new Presidential administration that comes every four to eight years creates another conundrum. A new President means a new National Security Strategy, often with substantial changes. This, in turn, creates an attendant instability in what

155. 37 C.F.R. $\$ 1.183(2020)$.

156. See 35 U.S.C. $\S 181$.

157. 37 C.F.R. $\S \S 5.1(\mathrm{a}), 5.4(\mathrm{a})$.

158. $§ 5.4(\mathrm{~d})$. 
technologies agencies will have made secret. The resultant uncertainty for inventors compounds the dissonance between the needed patent system incentives and the countervailing secrecy order disincentives.

\section{PRoposed MECHANISMS AND PROCEDURES TO RECTIFY THE IDENTIFIED ISSUES}

As can be seen from all of the above, it is abundantly clear that there is little to prevent the Government from severely abrogating the ability for private parties to acquire patents on their inventions. The incentivization of these monopolies lie at the heart of the patent system and have helped to keep technological advancement in the United States moving at a blistering pace. Concordantly, to preserve the integrity of the patent system, proper checks must be established against the Government in its issuance of secrecy orders.

First, a more clearly defined statutory system should be put in place that requires explicit information on why a particular invention is detrimental to national security. The initial burden for this should naturally fall on the Government, which must show how the associated technical information would enable enemies or adversaries to undermine present or contemplated future security infrastructure, how it could expand their (enemies' or adversaries') capabilities, et cetera. This would be presented to a special, non-defense agency panel ideally within the Department of Commerce but that consist of persons well versed in national security. Procedurally, this would occur in between the agency's in-house assessment and the secrecy order request being sent to the Director of Patents, thus, acting as a gatekeeping function.

The panel would conduct an ex parte proceeding in which it does a moderately thorough check on the veracity of the agency's assertions so as to prevent a rubber-stamp system from coming about, while also not creating an unmanageable administrative burden. If the agency's reasoning is lacking, then the panel will set a deadline by which the agency must respond with a more comprehensive report. If after the second attempt there is still insufficient evidence, or if the agency does not submit it in a timely manner, no secrecy order request will be allowed to go on to the Commissioner of Patents and the inventor's application will be prosecuted in a normal fashion. Alternatively, if the panel verifies the agency's assertions, it will allow the secrecy request to proceed to the Commissioner. As a precautionary measure, once the panel receives the agency's request, a temporary 
non-publication and non-issuance order will be placed on the associated application to prevent public revelation before the panel can complete its review.

For purposes of political accountability, it is important that elected officials select the panel's members. If the panel fails to properly fulfill its duties and slips into rubber stamping agency requests, then those persons at risk of being voted out of office are the ones who face public backlash for this. Concordantly, the elected representatives in question will have a vested interest in ensuring that the panel is acting as it should. The best choice vis-à-vis representatives is the House Judiciary Subcommittee on Courts, Intellectual Property, and the Internet; the Senate Judiciary Subcommittee on Intellectual Property; or a combination of the two. Conceptually, the panel would be analogous to the International Trade Commission: a quasi-judicial, bipartisan body whose members are appointed to set terms by the aforementioned Congressional subcommittee(s).

Second, stronger and more clearly delineated statutory mechanisms by which an applicant can challenge a secrecy order are needed. This should include the right to sue the Government before an impartial court, which is not free to make up whatever rules it desires, as is the case with the agencies and Secretary of Commerce. An inventor whose application has been made secret should have the ability to appeal the matter, not just to the Secretary of Commerce, but also to a United States federal court. The Court of Appeals for the Federal Circuit would be a good option as it already has subject-matter exclusivity over patent appeals and petitions coming from either the district courts or directly from the USPTO.

The statutes should prescribe a two-part analysis. First, the Court assesses the total potential harm to national security. If the potential harm is sufficiently high, then the inquiry comes to an end and the Court will affirm the secrecy order. The information classification protocols, which are already categorized by the harm that the nation would likely suffer if the associated information were to leak, inform where this bar resides. The burden for showing that the potential harm of a given application is sufficiently high falls on the Government.

If the potential harm is not sufficiently high, then the second part of the inquiry begins, where the Court performs a balance-of-interests test: on one side would be the potential harm to national security; on the other would be two primary, but non-exclusive, 
considerations. The first is the benefits to the public by having access to the invention. This includes both the literal invention's benefits to society brought about by the inventor's ability to make and use it, as well as other inventors' access to the invention disclosure from which they can further advance the state of the art. The second consideration is the commercial harm to the inventor that a secrecy order would cause. If the latter set of interests outweighs the former, then the Court will overturn the secrecy order, and the application will proceed with prosecution normally.

While an applicant must have the ability to have his or her case heard before an impartial court, it is equally important to not jeopardize national security by revealing sensitive information through an open trial. As an appellate court, the Federal Circuit already operates without a jury. For obvious reasons, if the trial were open to, or otherwise involved members of, the public, the open discussion of the application at issue would render any secrecy orders (including, importantly, ones that are merited and proper) as moot. An additional advantage of using the Federal Circuit is that its more centralized location aids in maintaining a more consistent security apparatus, vice the innumerable district courts that fall under a given circuit. This reduces the risk of a leak by way of, inter alia, a careless employee accidently discarding sealed court documents in an inappropriate manner; the documents should be destroyed, such as through burn-bags, like certain classified documents currently are. Additionally, by both of the above measures being statutorily created, 37 C.F.R. section 1.183 would be impotent against them, further preventing potential abuse.

An important caveat, however, must exist to this structure: emergency circumstances. The history of secrecy orders shows that the times in which they were deemed to be of the utmost importance was during periods of conflict. Because of the greatly increased potential for harm to the defense apparatus charged with protecting the citizenry during wartime, the system discussed above must have a measure of flexibility. While the panel would continue to exist, during wartime, the burdens placed on the Government would be reduced. Additionally, wartime would act only as the starting point. Congress could add other situations deemed appropriate to this "Emergency Circumstances List." As with panel member selection, however, by requiring Congress to modify it, there is still political accountability. 


\section{CONCLUSION}

The current invention secrecy order system requires a substantial overhaul. As it currently stands, there is vast potential for governmental overreach into private intellectual property rights with virtually no safeguards in place to act as a check against this. Defense agencies can have the USPTO place secrecy orders on applications effectively on a whim. By simply deciding that public revelation of information in a given application meets the low bar of being detrimental to national security, an agency can command the Commissioner of Patents to make the application secret. Further, how the agencies go about making this determination is left entirely to their discretion. Although affected applicants can seek financial compensation, they are de facto left without any meaningful way to challenge the validity of the secrecy order at the outset. The very real possibility of the Government preventing inventors from obtaining and thereafter leveraging a patent after they have already dedicated substantial time, money, and resources towards the endeavor could have a serious chilling effect on the development of new technologies. The benefits to the public from these new technologies is one of the core purposes of the patent system, and so, new statutory safeguards should be put in place.

A new statutorily-established system should be created. This would consist of a panel, which acts as a gatekeeper between the agencies and the USPTO. By requiring the agencies to provide evidence to the panel that shows that an application contains information that would damage national security, agencies will no longer be able to so freely have any applications falling within potentially entire SMAs be made secret. Additionally, an inventor should also be able to appeal the issuance of a secrecy order not just to the Secretary of Commerce, as is currently the case, but also to an impartial United States federal court. These inventor protections will alleviate the fears of Governmental abrogation of private patent rights, and the United States patent system will remain healthy and productive to the benefit of all. 